\title{
Investigating Customer Satisfaction of the Bakauheni-Palembang Toll Road
}

Dini Dwi Wulandary ${ }^{1}$

${ }^{1}$ Faculty of Economic-Universitas Negeri Jakarta-Indonesia

Agung Kresnamurti Rivai ${ }^{2}$, Rahmi $^{3}$

${ }^{2}$ Faculty of Economic-Universitas Negeri Jakarta-Indonesia

${ }^{3}$ Faculty of Economic-Universitas Negeri Jakarta-Indonesia

Correspondence: dini.wulandary04@gmail.com
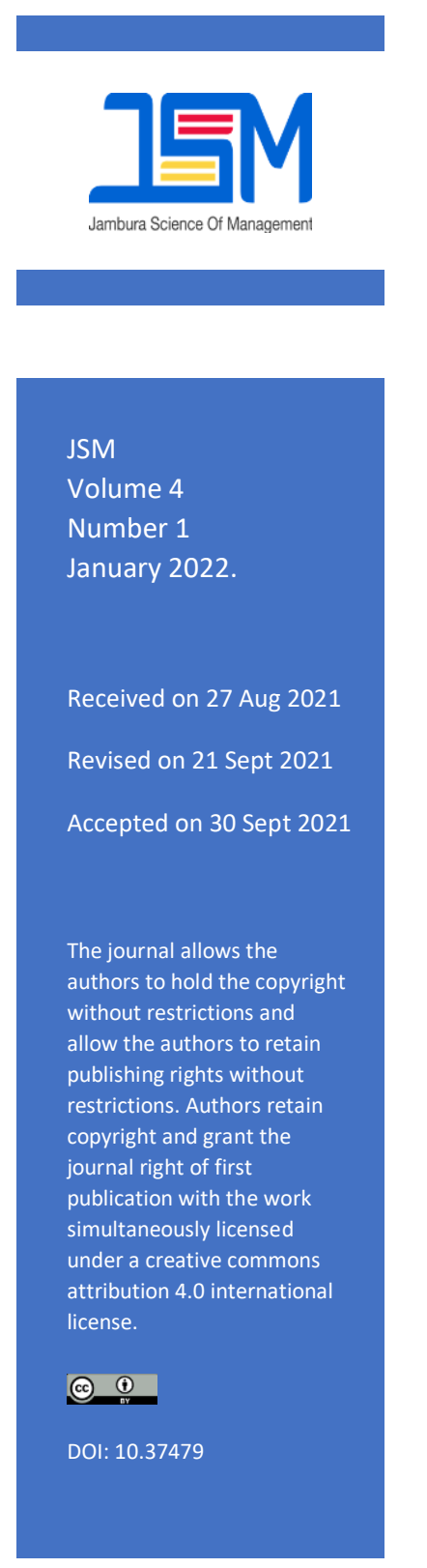

\section{ABSTRACT}

Purpose: This study aims to determine the effect of service quality, E-WOM, and perceived value on customer satisfaction of the Bakauheni-Palembang Toll Road.

Design/Methodology/Approarch: This study uses quantitative methods. Data collection technique using a survey method with an instrument in the form of a questionnaire. The sample in this study amounted to 200 respondents who have used the BakauheniPalembang Toll Road at least twice in the last year. Use SPSS 22 version and Lisrel 8.8 SEM (Structural Equation Model) for technical data analysis to process and analyze research data.

Findings: The results showed that service quality has no significant effect on E-WOM, service quality had no significant effect on customer satisfaction, the perceived value has a significant effect on E-WOM, perceived value has a significant effect on customer satisfaction, E-WOM has a significant impact on customer satisfaction, service quality has no significant effect on customer satisfaction through E-WOM, perceived value has a significant effect on customer satisfaction through E-WOM.

Keywords: Service Quality; E-WOM; Perceived Value; Customer Satisfaction; Bakauheni-Palembang Toll Road

\section{INTRODUCTION}

Sumatra Island is known as one of the largest islands in Indonesia with an area of about 443,065.8 square kilometres and has the secondfastest economic development after Java Island. The rapid economic activity on this island is support by the potential of rich natural resources and an easy-to-access location (Sosilowati, 2017). Sumatra's economic growth shows a positive growth trend. The contribution given to the state reached $21 \%$, second only to the island of Java. Agriculture, oil, gas and geothermal mining are the sectors with the most significant contributors. In addition to mining, another extraordinary potential is seasonal and annual plantations which reach $56.5 \%$. One of the most significant commodities is palm oil and 
rubber. If exports are still commodity-based, dependence on palm oil and rubber will not be profitable. In the future, Sumatra's economic development should no longer rely on non-renewable resources, should seek product diversification and follow the President's vision for downstream production so that exports are no longer commoditybased (Badan Pusat Statistik, 2019).

During from 2014 to 2019, President Joko Widodo and Vice President Jusuf Kalla wanted to increase competitiveness and narrow the gap between regions by improving relations with each other. In addition to socioeconomic disparities, infrastructure development is the most crucial field for national development (Daryono, 2017). One solution is to build the Trans Sumatra Toll Road. President Joko Widodo said this toll road would connect regions with regions and revitalize the Sumatran economy, develop new centres of economic growth, and develop nodes of productive economic growth. In addition, there is enormous development potential, including agriculture, plantations, tourism, and mining, to increase the monetary value of the resulting product (Asmara, 2021).

One of the Trans Sumatra toll roads that have been operating is the Bakauheni-Palembang Toll Road. Unfortunately, the existence of the Bakauheni-Palembang toll road still faces challenges. The reason is that there are still few vehicles that pass on the Bakauheni-Palembang Toll Road. In addition, several challenges must be faced, including the threat of criminal acts on toll roads, due to the lack of vehicles passing through toll roads. There are still many trucks with loads of more than standard capacity crossing the toll road, which causes the toll road to break down quickly. Damaged toll roads can threaten the safety of other toll road users (Al Hikam, 2020). Another problem faced by Trans Sumatra toll road users is the lack of lighting. Toll road lighting is only available at toll exits and entrances. Drivers are advised to be careful when deciding to cross the Trans Sumatra Toll Road at night. The Trans Sumatra Toll Road is equipped with rest areas along the road, but not all rest areas can be used (Ikhsan, 2020). Based on these problems, researchers feel the need to research the Bakauheni-Palembang Toll Road.

Service quality can make customers attach to specific products and services so that company performance can increase. In order to maintain service quality, customer satisfaction is an essential factor in retaining customers who meet market needs (Ibrahim and Thawil, 2019). As Cronin and Tailor in Japarianto (2019) explained, customer satisfaction is the most important aspect in determining service quality. Consumers can evaluate the performance of the services they receive and their direct feelings towards the service. Toll users on the internet site submit many complaints. The complaint is related to the number of potholes along the toll road. Through the development of information technology, information can be easily accessed by others. With the internet, it is possible to communicate with various kinds of 
media, and this communication is often known as E-WOM. E-WOM is important for consumers to think about the goods or services they have used because it can be accessed quickly and widely.

In line with Hennig-Thurau and Walsh in Utami et al. (2016), the internet provides various ways to obtain information about products or services from other consumers that also called electronic word of mouth (EWOM). Furthermore, according to Hennig-Thurau et al. in Utami et al. (2016) consumers who have used a company's products or services may or do make affirmative or negative statements, and many people and organizations can access them via the internet. Based on this, the researcher argues that the quality of services provided by the company can affect the ratings given by customers either directly or via the internet or social media. This is also consistent with previous research conducted by Oraedu et al. (2020), which shows that service quality can have a positive impact on satisfaction, and satisfaction has a positive impact on electronic word of mouth (EWOM).

Recognizing what customers value is critical for a business since a better understanding of what customers value will lead to increased customer satisfaction and a stronger competitive position, as stated by Fornell et al. in Ahmad Suryani and Alit Suryani (2016). Consumer appraisal of the usefulness of a product or service based on their view of the product received and delivered, also known as perceived value, is expressed by Zeithaml in Konuk (2018). This is consistent with prior research, which found that perceived value has a strong positive direct effect on customer satisfaction in a variety of retail and service situations, as revealed by Williams and Soutar in Slack et al. (2020). Based on this definition, the researcher argues that perceived value contributes to customer satisfaction with the products or services they use.

Many previous studies have looked at the relationship between Service Quality, E-WOM, and Perceived Value on Customer Satisfaction in order to build research models. However, there are still few previous studies that discuss E-WOM as an intervening variable. As a result, researchers propose that E-WOM be employed as a mediator between Service Quality and Customer Satisfaction, as well as Perceived Value and Customer Satisfaction. In addition, there are still few studies that discuss toll roads as research objects with service quality, E-WOM, perceived value, and customer satisfaction variables. Objects commonly used in the research of these variables are tourist attractions, restaurants and lodging or hotels.

When comparing a product's performance or perceived results with what is expected, satisfaction refers to a person's feelings of joy or disappointment derived from the consumption experience (Wirtz \& Lovelock, 2016). Furthermore, customer satisfaction is defined by Zeithalm et al. (2018) as a customer's assessment of whether a product or service meets their wants and expectations. Customer satisfaction 
is influenced by a variety of elements, including 1) product and service features, 2) customer emotions, 3) service success or failure qualities, 4) perception of justice or fairness, and 5) other customers, family members, and coworkers, according to Zeithalm et al. (2018).

According to Tjiptono in Rizan et al. (2019), The comparison between the company's level of service and consumer expectations is reflected in service quality. Customer demands and expectations are met, and the balance they provide or accuracy that exceeds customer expectations is reflected in service quality. According to Parasuraman, Zeithaml, and Berry in KresnamurtiRivaiP et al. (2019), service quality can be divided into five dimensions, namely Tangible, Reliability, Responsiveness, Assurance, and Empathy.

According to Hennig-Thurau, Gwinner, Walsh, and Gremler in Utami et al. (2016), Electronic Word of Mouth (E-WOM) is a possible or actual good or negative statement made by customers who have used a company's products or services, which may be accessed by a large number of individuals and institutions over the internet. Furthermore, Cheung and Lee in Darma \& Swari (2019) explain E-WOM refers to the communication and exchange of information between new and old consumers via technological developments such as online discussion forums, review sites, and websites, as well as social media platforms that allow communicators to exchange information.

The difference between the customer's estimate of all perceived advantages and costs incurred is known as customer-perceived value (Kotler \& Keller, 2016). According to Zeithaml in Konuk, (2018), A customer's complete opinion of the benefits of a product or service is based on two perceptions: what is received and what is given. Many theories suggest the meaning and dimensions of perceived value. In this study, researchers used the theory of perceived value from Wang et al. in Shaikh et al. (2018) because it can be used in research in the service industry which can be divided into four dimensions, including 1) Perceived Sacrifices, 2) Functional Value, 3) Emotional Value, and 4) Social Value.

The Internet has created a platform for quick information distribution. Consumers today may readily share their opinions on a product or service with others. Customers very often look for comments online to get information about a product or service. Pandey and Sahu (2020) have tested one of the same hypotheses that service quality affects EWOM. Service quality has a substantial and positive link with EWOM, according to the findings. Research conducted by Prayogo \& Kusumawardhani (2016) tested one of the same hypotheses that service quality positively affects E-WOM. Service quality has a good and significant impact on E-WOM, according to the findings. As a result, we suggest the theory below:

$\mathrm{H} 1$ = E-WOM is influenced by service quality in a positive and significant way.

P-ISSN: 2655-3651 E-ISSN: 2656-0435

P a g e | 32 
Service quality is a factor that can affect customer satisfaction. This thing happens when the quality of service provided can meet or exceed customer perceptions. KresnamurtiRivaiP et al. (2019) have tested the satisfaction of Grab online transportation users on Faculty of Economics students at the State University of Jakarta to determine the effect of each independent variable, one of which is service quality. The findings suggest that customer happiness for Grab online transportation consumers is influenced by service quality. SánchezFernández et al. (2020) did research the impact of service quality on customer satisfaction, the findings show that customer satisfaction is influenced by service quality in a favorable and significant way. As a result, we provide the following hypothesis:

$\mathrm{H} 2$ = Customer satisfaction is influenced by service quality in a positive and significant way.

The value perceived by the customer can affect the customer's intention to spread E-WOM. The value perceived by good customers will increase their intention to spread the E-WOM message. Uslu and Karabulut (2018) have tested one of the same hypotheses, namely perceived value influencing E-WOM. The results show that the perceived value of customers increases their intention to spread EWOM. The impact of tourists' perceived value on E-WOM was studied by Sukaris et al. (2020). The data show that the perceived value of tourism has an impact on E-WOM. As a result, we suggest the theory below:

$\mathrm{H} 3$ = E-WOM is influenced by perceived value in a positive and significant way.

Customer satisfaction is influenced by perceived value. Customers will be satisfied if all costs incurred correspond to the advantages experienced by the customer. The impact of perceived value on customer satisfaction was explored by Wu et al. (2018). Consumer satisfaction appears to be influenced by perceived value, according to the research. In the restaurant industry, Jalilvand et al. (2017) investigated the impact of perceived value on customer satisfaction. According to the study, perceived value has a positive impact on consumer satisfaction. As a result, we provide the following hypothesis:

$\mathrm{H} 4$ = Customer satisfaction is influenced by perceived value in a positive and significant way.

Consumers generally seek information from products or services to help determine their decision before making a purchase. EWOM has been one of the sources of information utilized by customers to make decisions as the internet and social media have grown in popularity. Kuo and Nakhata (2019) has tested the relationship between consumer satisfaction and retail players. The results show that the positive (negative) impact of E-WOM before consumers make a purchase can increase (decrease) consumer satisfaction. When 
customers are less driven to absorb information in a challenging way, E-WOM will have a greater impact. Tandon et al. (2020) has tested the impact of E-WOM on customer satisfaction in e-commerce. EWOM has a strong and significant effect on customer satisfaction, according to the findings. Therefore, we propose the following hypothesis:

H5 = Customer satisfaction is influenced by E-WOM in a positive and significant impact.

Reviews given by customers who have experienced the quality of service found through websites or social media can lead to overall customer satisfaction. The researcher employs the E-WOM variable as a mediating variable between service quality and customer satisfaction to investigate if it has an indirect effect on the relationship between service quality and customer satisfaction. Xu (2021) investigated into customers' online review writing habits and general satisfaction with high-demand delivery restaurants. Through internet reviews, the researchers discovered the drivers of customer satisfaction with restaurants. Furthermore, service quality has an impact on total customer satisfaction. Therefore, we propose the following hypothesis:

H6 = E-WOM has a positive and significant impact on Customer Satisfaction by mediating the influence of Service Quality.

Customer perceptions of value are affected by service quality. Customer perceived value can influence and strengthen their satisfaction. The researcher uses the E-WOM variable as a variable that mediates the relationship between perceived value and customer satisfaction to investigate if it has an indirect effect on the relationship between perceived value and customer satisfaction. One of the same assumptions was explores by Rosifa et al. (2020), namely that EWOM mediates the association between customer perceived value and customer satisfaction. The findings demonstrate that E-WOM has a substantial role in mediating the relationship between perceived value and customer satisfaction. As a result, we suggest the theory below:

$\mathrm{H} 7$ = E-WOM has a positive and significant impact on Customer Satisfaction through mediating the influence of Perceived Value.

\section{METHODS}

The quantitative research method was applied in this investigation. Quantitative methods are used to examine specific populations or samples utilizing research instruments for data collection and analysis of quantitative or statistical data with the goal of testing prepared hypotheses, according to Sugiyono (2019).

The sample is a subset of the population's characteristics (Sugiyono, 2019:127). Purposive sampling was utilized as a sample approach in this study. The sample criteria used in this study are Bakauheni- 
Palembang Toll Road users who have used the Bakauheni-Palembang Toll Road at least twice in the last year.

The specified requirements determine the determination of the number of samples. Based on Hair et al. (2013) The number of samples taken is at least five times that of the study's parameters. Further, Hair et al. (2013) stated that the minimum sample size for LISREL analysis is 200 samples. As a result, the researcher determined that a minimum of 200 samples would be required for this investigation.

Data were obtained from distributing questionnaires distributed to users of the Bakauheni-Palembang Toll Road as many as 200 respondents. The data will be used to test the variables in this study. Researchers get data offline by coming directly to the BakauheniPalembang Toll Gate. The researcher has prepared a poster containing a QR Code. After this, the researcher asked permission from the users of the Bakauheni-Palembang Toll Road whether or not they are willing to become respondents. If they are willing, the respondent can immediately scan the QR Code on the poster. In addition, researchers also obtained data online by providing links to twitter social media users and groups on Facebook social media.

In this study, researchers used a Likert measurement scale. The Likert scale, according to Sugiyono (2019), reflects a person's or group's attitudes, opinions, and point of view about social phenomena. The measurement scale employed is a five-point Likert scale with five response categories ranging from "Strongly Agree" to "Strongly Disagree," which asks respondents to choose whether they agree or disagree with a series of statements about the stimulus object. According to Hameed et al. (2018), the use of a five-category Likert scale will increase the level and quality of answers and reduce the "frustration level" of respondents.

In processing and analyzing the research data, the researcher used SPSS 22 and SEM (Structural Equation Model) from the statistical package LISREL 8.8. According to (Sanusi, 2011), SEM software can not only detect causality relationships (direct and indirect) on observed variables or constructs, but it can also determine the magnitude of the components that contribute to the construct's formation, making the causal relationship between variables or constructs more insightful, complete, and accurate. Lisrel can identify complex relationships between variables and can process either by writing in a programming language or not. 


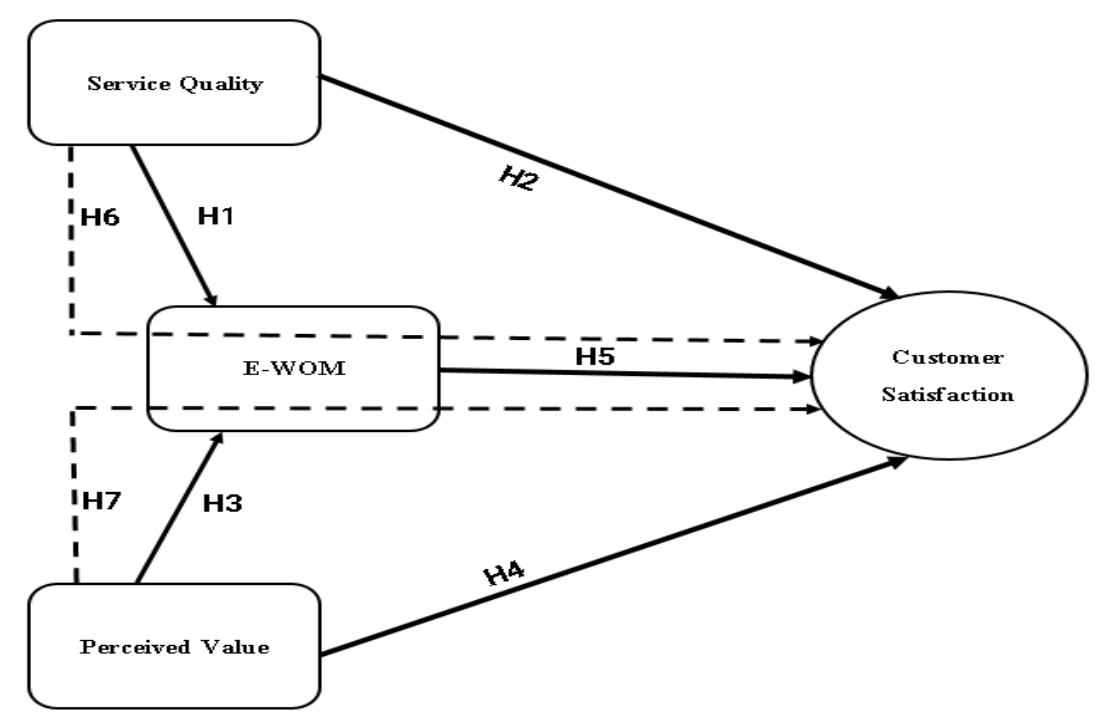

Figure 1. Research Model

Source: Data processed by researchers (2021)

\section{RESULTS}

Of the 200 respondents who have filled out the questionnaire, the results show that most respondents are women, as much as $55 \%$. The respondents who filled out the most surveys were between the ages of 21 and 25, accounting for 32 percent of the total. Employees made up the majority of respondents, accounting for 28 percent, with the majority of respondents earning between Rp. 2,500,001 and Rp. 7,500,000, accounting for 35 percent.

\section{Validity and Reliability Test}

In this study, the validity test is performed using the Pearson test, and the indicator is regarded valid if the obtained $r$-value is bigger than the r-table. The r-table in this study is 0.138 , with a $5 \%$ significant level, and 200 samples were used. So each indicator is said to be valid if the calculated r-value is more significant than 0.138 . The results show that the indicators used in this study are valid and can be used to measure and test data from the variables studied appropriately.

Table 1. Validity Test Result

\begin{tabular}{ccccc}
\hline Variables & Indicators & $\mathbf{r}$-value & $\begin{array}{c}\text { r-table 5\% } \\
(\mathbf{N}=\mathbf{2 0 0})\end{array}$ & Explanation \\
\hline SQ1 & 0,508 & 0,138 & Valid \\
SQ2 & 0,505 & 0,138 & Valid \\
SQ3 & 0,568 & 0,138 & Valid \\
SQ4 & 0,590 & 0,138 & Valid \\
SQ5 & 0,719 & 0,138 & Valid \\
& SQ6 & 0,683 & 0,138 & Valid \\
SQ7 & 0,221 & 0,138 & Valid \\
& SQ8 & 0,687 & 0,138 & Valid \\
SQ9 & 0,561 & 0,138 & Valid \\
SQ10 & 0,712 & 0,138 & Valid \\
SQ11 & 0,700 & 0,138 & Valid \\
\hline
\end{tabular}




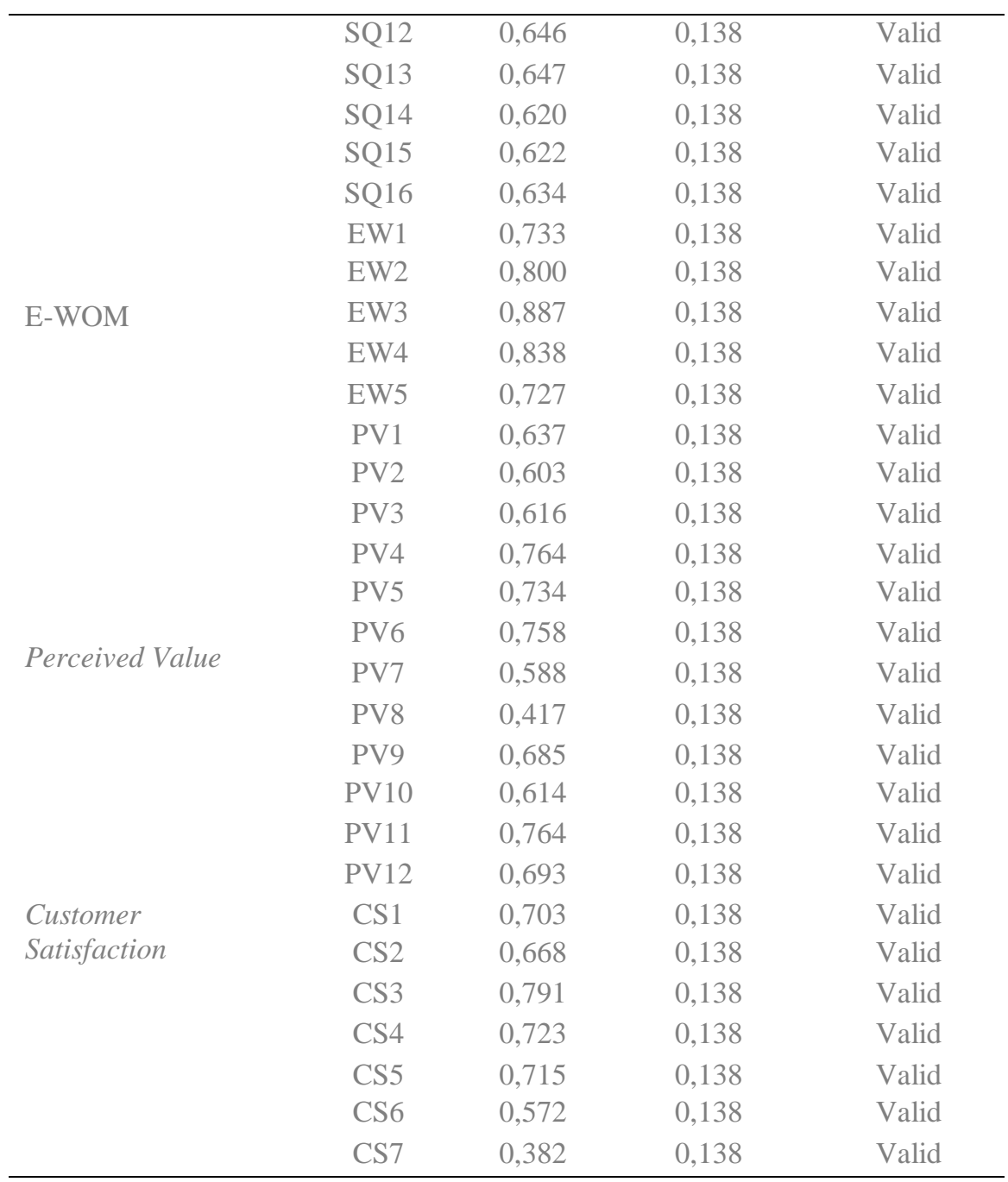

Source: Data processed (2021)

The Cronbach's alpha approach is used in this study to determine whether an indicator is dependable if its reliability coefficient value (Cronbach's alpha) is larger than 0.6. The results show that all indicators used in this study are reliable as a data measuring tool.

Table 2. Reliability Test Result

\begin{tabular}{lcl}
\hline \multicolumn{1}{c}{ Variables } & $\begin{array}{c}\text { Cronbach's } \\
\text { Alpha }\end{array}$ & Explanation \\
\hline Service Quality & 0,885 & Reliable \\
E-WOM & 0,855 & Reliable \\
Perceived Value & 0,880 & Reliable \\
Customer Satisfaction & 0,779 & Reliable \\
\hline
\end{tabular}

Source: Data processed (2021)

\section{Confirmatory Factor Analysis}

Confirmatory factor analysis (CFA) is a technique used in SEM to see if the indicator variable is the same as the latent variable being investigated. Researchers used first-order confirmatory analysis in this study, where one latent variable was constructed from several indicator variables. The loading factor used is a minimum of 0.5. 
Factor loading indicates that all items have a significant load on the appropriate constructs. According to Hair et al. (2013), a good rule is that standardized loading estimates must be around 0.5 or higher, and the ideal is 0.7 or higher.

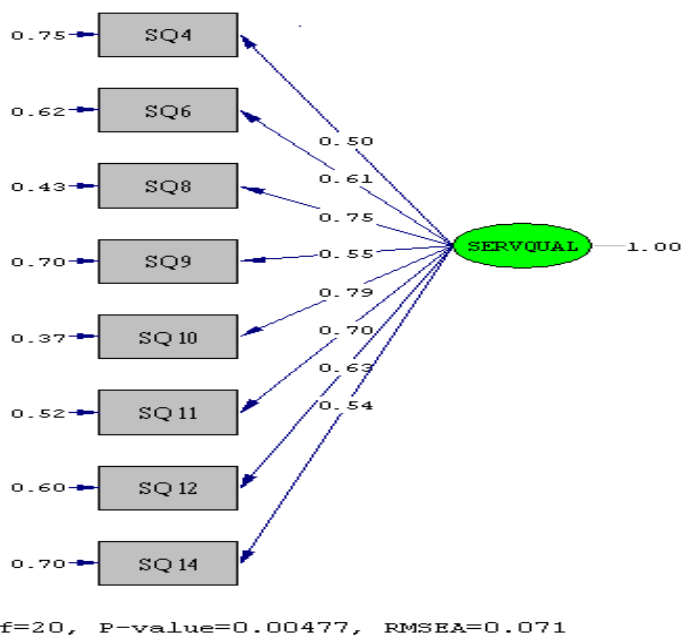

Figure 2. Service Quality First Order Construct Model

Source: Data processed (2021)

The service quality variable comprises 16 indicators while testing the device. Despite this, eight indicators must be removed after processing the model using the first-order construct since their loading factor value is less than 0.5 . Because if left unchecked, it will affect the value of Goodness Fit of Indices to be less good, so the researcher makes adjustments so that the value meets the index value. The Good Fit Indices test can be good because it has acceptable goodness of fit test results in the expected range. Outcome of testing service quality, CMIN/DF 2,00; GFI 0,95; RMR 0,03; RMSEA 0,07; AGFI 0,91; TLI/NNFI 0,97; CFI 0,98.

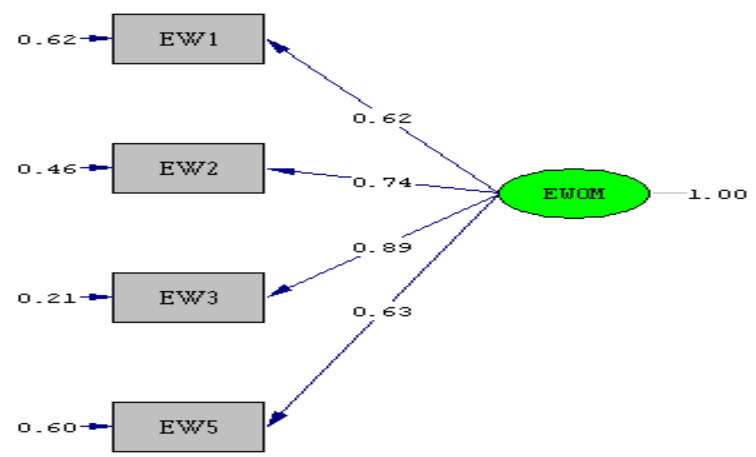

Chi-square=6.97, df=2, P-value=0.03060, RMSEA=0.112

Figure 3. E-WOM First Order Construct Model

Source: Data processed (2021) 
There are five indicators in the E-WOM variable instrument test findings. However, one indicator must be removed after processing the model using the first-order construct since its loading factor value is less than 0.5. Because if left unchecked, it will affect the value of Goodness Fit of Indices to be less good, so the researcher makes adjustments so that the value meets the index value. The Good Fit Indices test can be pretty good because it has acceptable goodness of fit test results in the expected range. Outcome of testing E-WOM, CMIN/DF 3,55; GFI 0,98; RMR 0,02; RMSEA 0,11; AGFI 0,91; TLI/NNFI 0,96; CFI 0,99

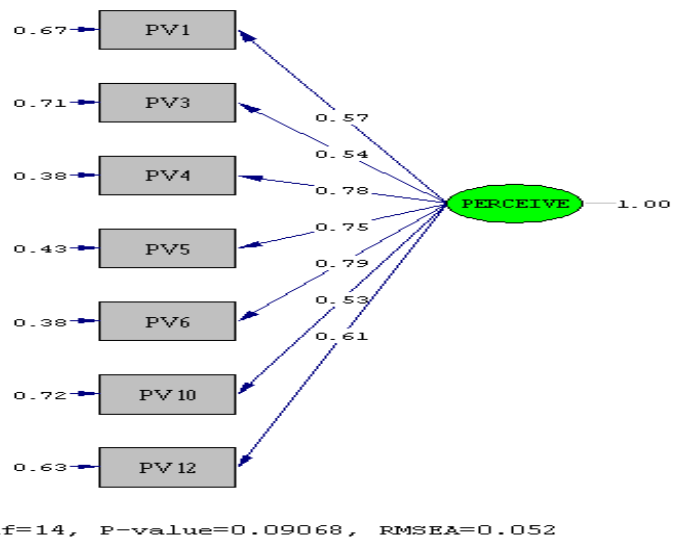

Figure 4. Perceived Value First Order Construct Model

Source: Data processed (2021)

The perceived value variable has 12 signs while testing the instrument. Despite this, five indicators must be removed after processing the model using the first-order construct since their loading factor value is less than 0.5. The test of good fit indices on the perceived value variable can be good because it has good fit test results that can be accepted in the expected range. Outcome of testing perceived value, CMIN/DF 1,53; GFI 0,97; RMR 0,02; RMSEA 0,05; AGFI 0,94; TLI/NNFI 0,98; CFI 0,95.

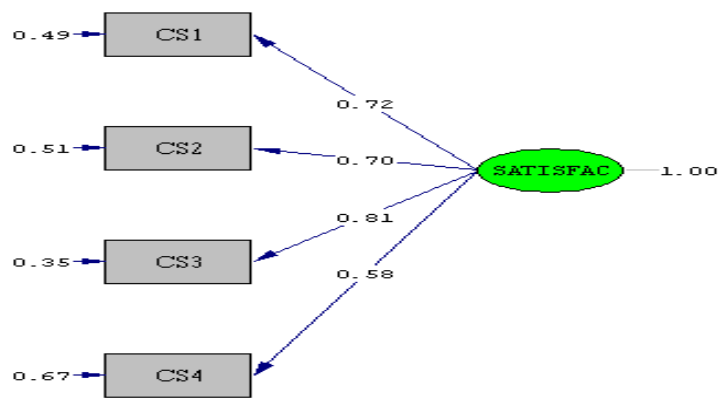

Chi-square=7.02, df=2, P-value=0.02996, RMSEA=0.112

Figure 5. Customer Satisfaction First Order Construct Model

Source: Data processed (2021) 
There are seven indicators in the Customer Satisfaction variable instrument test findings. However, three indicators must be removed after processing the model using the first-order construct since their loading factor value is less than 0.5. The Good Fit Indices test can be pretty good because it has acceptable goodness of fit test results in the expected range. Outcome of testing customer satisfaction, CMIN/DF 3,5; GFI 0,98; RMR 0,01; RMSEA 0,11; AGFI 0,91; TLI/NNFI 0,95; CFI 0,98 .

\section{Hypothesis Test}

If the standardized total effect is positive in hypothesis testing, there is a positive association between the variables. Still, if the result is negative, there is no positive relationship between one variable and another. Assume that the t-values are greater than 1.96. There is a substantial relationship between the two variables evaluated in that case, but if the number is less than 1.96, the relationship is not significant, then the variables do not have a meaningful relationship. There are 7 hypotheses that have been tested by the researcher. The following is an explanation of each hypothesis.

\section{Table 3. Structural Equation Model Test Results}

\begin{tabular}{|c|c|c|c|c|c|c|}
\hline $\mathrm{H}$ & $\begin{array}{c}\text { Independent } \\
\text { Variables }\end{array}$ & & $\begin{array}{c}\text { Dependent } \\
\text { Variables }\end{array}$ & $\begin{array}{c}\text { Standar } \\
\text { dized } \\
\text { Total } \\
\text { Effect } \\
\end{array}$ & $\begin{array}{c}\text { T- } \\
\text { Value }\end{array}$ & $\begin{array}{c}\text { Interpretati } \\
\text { on }\end{array}$ \\
\hline $\mathrm{H}_{1}$ & $\begin{array}{l}\text { Service } \\
\text { Quality }\end{array}$ & $\rightarrow$ & E-WOM & 0,28 & 1,71 & $\begin{array}{c}\text { Positive } \\
\text { Not } \\
\text { significant }\end{array}$ \\
\hline $\mathrm{H}_{2}$ & $\begin{array}{l}\text { Service } \\
\text { Quality }\end{array}$ & $\rightarrow$ & $\begin{array}{l}\text { Customer } \\
\text { Satisfaction }\end{array}$ & $-0,29$ & 1,67 & $\begin{array}{c}\text { Not } \\
\text { significant }\end{array}$ \\
\hline $\mathrm{H}_{3}$ & $\begin{array}{l}\text { Perceived } \\
\text { Value }\end{array}$ & $\rightarrow$ & E-WOM & 0,43 & 2,60 & $\begin{array}{l}\text { Positive } \\
\text { Significant }\end{array}$ \\
\hline $\mathrm{H}_{4}$ & $\begin{array}{l}\text { Perceived } \\
\text { Value }\end{array}$ & $\rightarrow$ & $\begin{array}{l}\text { Customer } \\
\text { Satisfaction }\end{array}$ & 0,80 & 4,32 & $\begin{array}{l}\text { Positive } \\
\text { Significant }\end{array}$ \\
\hline $\mathrm{H}_{5}$ & E-WOM & $\rightarrow$ & $\begin{array}{l}\text { Customer } \\
\text { Satisfaction }\end{array}$ & 0,23 & 2,18 & $\begin{array}{c}\text { Positive } \\
\text { Significant }\end{array}$ \\
\hline $\mathrm{H}_{6}$ & $\begin{array}{l}\text { Service } \\
\text { Quality }\end{array}$ & $\begin{array}{c}\text { E- } \\
\text { WOM }\end{array}$ & $\begin{array}{l}\text { Customer } \\
\text { Satisfaction }\end{array}$ & 0,28 & 1,23 & $\begin{array}{c}\text { Positive } \\
\text { Not } \\
\text { Significant }\end{array}$ \\
\hline $\mathrm{H}_{7}$ & $\begin{array}{l}\text { Perceived } \\
\text { Value }\end{array}$ & $\begin{array}{c}\text { E- } \\
\text { WOM }\end{array}$ & $\begin{array}{l}\text { Customer } \\
\text { Satisfaction }\end{array}$ & 0,80 & 1,96 & $\begin{array}{c}\text { Positive } \\
\text { Significant }\end{array}$ \\
\hline
\end{tabular}

Source: Data processed (2021)

In the structural equation model, seven hypotheses have been tested. The results show that service quality has no significant effect on EWOM. This is in line with the findings of Serra-Cantallops et al. (2020) and Oraedu et al. (2020), who found that service quality had a favorable but not statistically significant impact on E-WOM. Furthermore, consumer satisfaction is unaffected by service quality. This follows the research of Wang et al. (2019), which states that service quality does not significantly affect customer satisfaction. The exact relationship also occurs in service quality to customer satisfaction through E-WOM that the relationship between the three 
variables is insignificant. This is in line with the findings of Lufiana (2007) who found that E-WOM did not significantly mediate the influence of service quality on customer satisfaction.

\section{DISCUSSION}

Based on the results of the study, to improve service quality to customer satisfaction of the Bakauheni-Palembang Toll Road, more attention is needed to service quality which on average gets a positive response from respondents. However, there are still many passengers who give negative responses to the quality of street lighting. From these results, it can be seen that the Bakauheni-Palembang Tollgate officers can increase customer satisfaction, but users are disturbed by the lack of lighting along the Bakauheni-Palembang Toll Road. It would be better if the manager provides lighting throughout the Bakauheni Palembang Toll Road not only around the toll gate so that users who pass through the Bakauheni-Palembang Toll Road at night can feel safe.

Based on the results of the study, the E-WOM variable on average received a positive response from the respondents. So from these results, it can be concluded that the Bakauheni-Palembang Toll Road must maintain service quality and customer satisfaction so that customers can discuss and provide positive comments on social media about the Bakauheni-Palembang Toll Road.

On the perceived value variable, the average respondent gave a positive response. From these results, it can be concluded that the manager of the Bakauheni-Palembang Toll Road must always provide toll rates for users who are following the quality of services provided and by using the Bakauheni-Palembang Toll Road does not provide social recognition for users.

On the customer satisfaction variable, the average respondent gave a positive response. From these results, it can be seen that overall the Bakauheni-Palembang Toll Road is following user expectations and users are satisfied with their decision tousing the BakauheniPalembang toll road.

\section{CONCLUSION}

The first, second, and sixth hypotheses cannot be accepted. This is following the results of the standardized total effects test, and the tvalue is below 1.96. While the third, fourth, fifth, and seventh hypotheses can be accepted. This is following the standardized total effects test results, and the t-value is more than 1.96 .

Based on the study results, to improve service quality to customer satisfaction of the Bakauheni-Palembang Toll Road, the researcher suggests maintaining service quality and customer satisfaction so that customers can discuss and provide positive comments on social media about the Bakauheni-Palembang Toll Road. In addition, the manager

P-ISSN: 2655-3651 E-ISSN: 2656-0435

P a g e 41 
of the Bakauheni-Palembang Toll Road must always offer toll rates to users following the quality of the services provided and using the Bakauheni-Palembang Toll Road does not offer social recognition for its users. Overall, the Bakauheni-Palembang Toll Road follows user expectations, and users are satisfied with their decision to use the Bakauheni-Palembang Toll Road.

\section{RECOMMENDATION}

Research can be developed by establishing different research models, the number of samples of more than 200 respondents, and the selection of different characteristics of respondents so that research can provide wider results from various other possibilities.

Future research is expected to be able to use the variable perceived value as an intervention in research on toll roads on customer satisfaction. Research can be developed by investigating what perceived value variables affect the object of toll road research.

\section{REFERENCES}

Ahmad Suryani \& Alit Suryani, A. (2016). PERAN CUSTOMER PERCEIVED VALUE PADA KEPUASAN PELANGGAN Fakultas Ekonomi dan Bisnis Universitas Udayana, Bali, Indonesia Email : rifaiahmadhanif@gmail.com ABSTRAK Era globalisasi menuntut perusahan menyiasati perubahan bisnis dan dapat memanfaatkan pelua. 5(6), 3305-3334.

Al Hikam, H. A. (2020). Tol Trans Sumatera Masih Sepi, Ini 3 Faktanya. $\quad$ https://finance.detik.com/infrastruktur/d$\underline{\text { 5270188/tol-trans-sumatera-masih-sepi-ini-3-faktanya }}$

Badan Pusat Statistik. (2019). Ekonomi Sumatra Masih Tergantung Alam. https://www.bps.go.id/news/2019/07/22/302/ekonomisumatra-masih-tergantung-alam.html

Darma, G. S., \& Swari, D. A. K. B. A. (2019). Kepercayaan Lintas Generasi Dalam Penggunaan Social Media dan Electronic Word of Mouth Dewa Ayu Ketut Bintang Arbina Swari (1) Gede Sri Darma (2). Bisnis, Jurnal Manajemen, 16(4), 145-161.

Hair, J. F., Black, W. C., Babin, B. J., \& Anderson, R. E. (2013). Multivariate Data Analysis. In Pearson New International Edition (7th ed.). Pearson.

Ibrahim, M., \& Thawil, S. M. (2019). Pengaruh Kualitas Produk Dan Kualitas Pelayanan Terhadap Kepuasan Konsumen. Jurnal Riset Manajemen Dan Bisnis (JRMB) Fakultas Ekonomi UNIAT, 4(1), 175-182. https://doi.org/10.36226/jrmb.v4i1.251 
Ikhsan, M. (2020). Menjajal Tol Bakauheni-Palembang. https://www.cnnindonesia.com/teknologi/20200110154027384-464244/menjajal-tol-bakauheni-palembang

Jalilvand, M. R., Salimipour, S., Elyasi, M., \& Mohammadi, M. (2017). Factors influencing word of mouth behaviour in the restaurant industry. Marketing Intelligence and Planning, 35(1), 81-110. https://doi.org/10.1108/MIP-02-2016-0024

Japarianto, E. (2019). PENGARUH RETAIL SERVICE QUALITY TERHADAP MINAT BERKUNJUNG ULANG MALL Di SURABAYA MELALUI PERCEIVED QUALITY DAN CUSTOMER SATISFACTION SEBAGAI VARIABEL INTER VENING. Jurnal Manajemen Pemasaran, 13(1), 17-26. https://doi.org/10.9744/pemasaran.13.1.17-26

Konuk, F. A. (2018). The role of store image, perceived quality, trust and perceived value in predicting consumers' purchase intentions towards organic private label food. Journal of Retailing and Consumer Services, 43(April), 304-310. https://doi.org/10.1016/j.jretconser.2018.04.011

Kotler, P., \& Keller, K. L. (2016). Marketing Management Global Edition (Vol. $15 \mathrm{E})$. https://doi.org/10.1080/08911760903022556

KresnamurtiRivaiP, A., Suneni, \& Febrilia, I. (2019). Pengaruh Kualitas Pelayanan, Harga Dan Citra Merek Terhadap Kepuasan Konsumen Pengguna Transportasi Ojek Online Grab. Riset Manajemen Sains Indonesia (JRMSI), 10(1), 204-225. https://doi.org/http://doi.org/10.21009/JRMSI

Kuo, H. C., \& Nakhata, C. (2019). The Impact of Electronic Wordof-Mouth on Customer Satisfaction. Journal of Marketing Theory and Practice, 27(3), 331-348. https://doi.org/10.1080/10696679.2019.1615840

Oraedu, C., Izogo, E. E., Nnabuko, J., \& Ogba, I. E. (2020). Understanding electronic and face-to-face word-of-mouth influencers: an emerging market perspective. Management Research Review, 44(1), 112-132. https://doi.org/10.1108/MRR-02-2020-0066

Pandey, A., \& Sahu, R. (2020). Modeling the relationship between service quality, destination attachment and eWOM intention in heritage tourism. International Journal of Tourism Cities, 6(4), 769-784. https://doi.org/10.1108/IJTC-08-2019-0125

Prayogo, R. R., \& Kusumawardhani, A. (2016). Examining Relationships of Destination Image, Service Quality, e-WOM, 
and Revisit Intention to Sabang Island, Indonesia. Asia Pacific Management and Business Application, 5(2), 85-96. https://doi.org/10.21776/ub.apmba.2016.005.02.3

Rizan, M., Haro, A., \& Rahmadhina, B. (2019). PENGARUH PERCEIVED EASE OF USE DAN SERVICE QUALITY TERHADAP CUSTOMER SATISFACTION DENGAN TRUST SEBAGAI INTERVENING(STUDI KASUS PADA PENGGUNA GRAB DI WILAYAH JAKARTA). Jurnal Riset Manajemen Sains Indonesia (JRMSI), Vol 10, 337-355. https://doi.org/doi.org/10.21009/JRMSI.010.2.06

Rosifa, A., Suprihartini, L., \& Kurniawan, R. (2020). Pengaruh Nilai Pelanggan Dan Electronic Word Of Mouth Terhadap Kepuasan Pengunjung Dengan Keputusan Berkunjung Sebagai Variabel Intervening Pada New Marjoly Beach And Resort. Bahtera Inovasi, 4(1), 64-76. https://doi.org/10.31629/bi.v4i1.2759

Sánchez-Fernández, M. D., Álvarez-Bassi, D., \& Ramón-Cardona, J. (2020). Management of tourist destinations: The expectations of guests on eWOM generation in Maldonado (Uruguay). Sustainability (Switzerland), 12(17). https://doi.org/10.3390/SU12176825

Shaikh, A. A., Karjaluoto, H., \& Häkkinen, J. (2018). Understanding moderating effects in increasing share-of-wallet and word-ofmouth: A case study of Lidl grocery retailer. Journal of Retailing and Consumer Services, 44(February), 45-53. https://doi.org/10.1016/j.jretconser.2018.05.009

Slack, N., Singh, G., \& Sharma, S. (2020). Impact of perceived value on the satisfaction of supermarket customers: developing country perspective. International Journal of Retail and Distribution Management, 48(11), 1235-1254. https://doi.org/10.1108/IJRDM-03-2019-0099

Sukaris, S., Hartini, S., \& Mardhiyah, D. (2020). The effect of perceived value by the tourists toward electronic word of mouth activity: the moderating role of conspicuous tendency. Jurnal Siasat Bisnis, 24(1), 1-17. https://doi.org/10.20885/jsb.vol24.iss1.art1

Tandon, A., Aakash, A., \& Aggarwal, A. G. (2020). Impact of EWOM, website quality, and product satisfaction on customer satisfaction and repurchase intention: moderating role of shipping and handling. International Journal of Systems Assurance Engineering and Management, 11(s2), 349-356. https://doi.org/10.1007/s13198-020-00954-3 
Uslu, A., \& Karabulut, A. N. (2018). Touristic Destinations' Perceived Risk and Perceived Value As Indicators of E-Wom and Revisit Intentions. International Journal of Contemporary Economics and Administrative Sciences, 8(February), 37-63.

Utami, V. K., Tanujaya, D., \& Jokom, R. (2016). Analisa Faktor Yang Penting Dari Dimensi Electronic Word of Mouth (Ewom) Bagi Konsumen Dalam Memilih Hotel Di Situs Online Travel Agent (Ota). Jurnal Manajemen Pemasaran, 9(2), 78-85. https://doi.org/10.9744/pemasaran.9.2.78-86

Wirtz, J., \& Lovelock, C. (2016). Service Marketing: People, Technology, Strategy.

Wu, J. (Snow), Law, R., \& Liu, J. (2018). Co-creating value with customers: a study of mobile hotel bookings in China. International Journal of Contemporary Hospitality Management, 30(4), 2056-2074. https://doi.org/10.1108/IJCHM-08-2016-0476

$\mathrm{Xu}, \mathrm{X}$. (2021). What are customers commenting on, and how is their satisfaction affected? Examining online reviews in the ondemand food service context. Decision Support Systems, 142, 113467. https://doi.org/10.1016/j.dss.2020.113467

Zeithmal, V. A., Bitner, M. J., \& Gremler, D. D. (2018). Services Marketing: Integrating Customer Focus Across the Firm (Seventh). McGraw-Hill Education. 